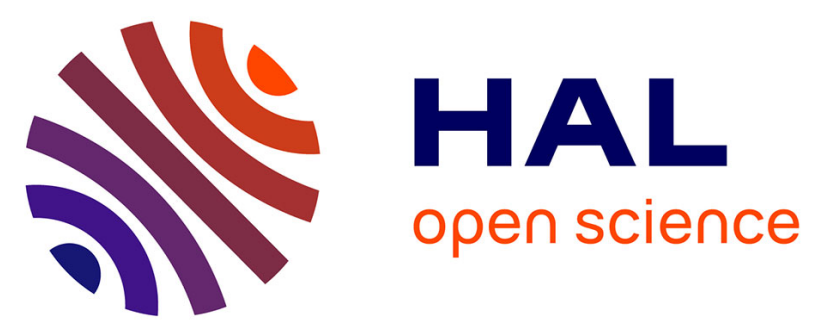

\title{
A Ruthenium Complex-Catalyzed Cyclotrimerization of Halodiynes with Nitriles. Synthesis of 2- and 3-Halopyridines
}

\author{
Eva Bednářová, Evelina Colacino, Frédéric Lamaty, Martin Kotora
}

\section{- To cite this version:}

Eva Bednářová, Evelina Colacino, Frédéric Lamaty, Martin Kotora. A Ruthenium Complex-Catalyzed Cyclotrimerization of Halodiynes with Nitriles. Synthesis of 2- and 3-Halopyridines. Advanced Synthesis and Catalysis, 2016, 358 (12), pp.1916-1923. 10.1002/adsc.201600127 . hal-02385428

\section{HAL Id: hal-02385428 \\ https://hal.science/hal-02385428}

Submitted on 3 Feb 2021

HAL is a multi-disciplinary open access archive for the deposit and dissemination of scientific research documents, whether they are published or not. The documents may come from teaching and research institutions in France or abroad, or from public or private research centers.
L'archive ouverte pluridisciplinaire HAL, est destinée au dépôt et à la diffusion de documents scientifiques de niveau recherche, publiés ou non, émanant des établissements d'enseignement et de recherche français ou étrangers, des laboratoires publics ou privés. 


\title{
A Ruthenium Complex-Catalyzed Cyclotrimerization of Halo- diynes with Nitriles. Synthesis of 2- and 3-Halopyridines
}

\author{
Eva Bednářová,, ${ }^{\mathrm{a}, \mathrm{b}}$ Evelina Colacino, ${ }^{\mathrm{b}}$ Frédéric Lamaty, ${ }^{\mathrm{b}, *}$ and Martin Kotora ${ }^{\mathrm{a}, *}$ \\ a Department of Organic Chemistry, Faculty of Science, Charles University in Prague, Albertov 6, 12843 Praha 2, Czech \\ Republic \\ Fax: (+420)-221-951-326; phone: (+420)-221-951-058; e-mail: martin.kotora@natur.cuni.cz \\ b Institut des Biomolécules Max Mousseron (IBMM), UMR 5247, CNRS-Université Montpellier-ENSCM, Université de \\ Montpellier, Campus Triolet, Place Eugène Bataillon, 34095 Montpellier Cedex 5, France \\ Fax: (+33)-(0)4 6714-4866; phone: (+33)-(0)4-6714-3847; e-mail: frederic.lamaty@umontpellier.fr
}

\begin{abstract}
Monohalo- and dihalodiynes efficiently undergo $[2+2+2]$ cyclotrimerization with nitriles in the presence of a catalytic amount of the ruthenium complex $\mathrm{Cp} * \mathrm{RuCl}(\mathrm{cod})(10 \mathrm{~mol} \%)$ to afford the corresponding halopyridines under ambient conditions in good isolated yields (up to $90 \%$ ). The halopyridines are formed as two separable regioisomers. This is the first example of a direct synthesis of halopyridines from haloalkynes and nitriles.
\end{abstract}

Keywords: alkynes; cyclotrimerization; homogeneous catalysis; nitrogen heterocycles; ruthenium

Pyridines and their more complex derivatives are an important class of heteroaromatic compounds. Substances possessing the pyridine framework are found in numerous branches of chemistry. ${ }^{[1]}$ Out of many synthetic methods used for their preparation, ${ }^{[2]}$ perhaps the simplest and the most efficient, is catalytic cyclotrimerization of alkynes with nitriles by using transition metal compounds. ${ }^{[3]}$

Although a number of catalytic protocols have been developed, there is still a considerable space to explore cyclotrimerization for hitherto untried combinations of alkynes and nitriles. In this respect, it would be desirable to develop a procedure allowing synthesis of pyridines possessing a reactive functional group on the pyridine scaffold that would allow further transformations. It would be synthetically interesting if a cyclotrimerization would allow formation of halopyridines by a catalytic reaction of haloalkynes with nitriles.

As far as the cyclotrimerization of chloro-, bromoand iodoalkynes is concerned, they can efficiently react with alkynes in cyclotrimerization processes to give the corresponding halobenzenes. These processes include: (i) $\mathrm{Ru}$ - or Co-catalyzed reactions of monoiododiynes and diiododiynes ${ }^{[4]}$ with alkynes to iodobenzenes that were further functionalized by cross-coupling reactions; $;{ }^{[5]}$ (ii) $\mathrm{Ru}$ - or Rh-catalyzed cyclotrimerization of monobromodiynes with alkynes as a route to new potentially selective inhibitors of tyrosine kinase $2 ;{ }^{[6]}$ (iii) Ru-catalyzed cyclotrimerization of a highly substituted chlorodiyne and alkyne during the course of the sporolide B synthesis. ${ }^{[7]}$ Although, a Ru-complex catalyzed cycloaddition of haloalkynes with nitrile oxides and organic azides has been recently described, ${ }^{[8]}$ their cyclotrimerization with nitriles providing halopyridines, interestingly, has not been reported so far (to the best of our knowledge). Our interest in cyclotrimerization of the halodiynes with the nitriles stemmed for the fact that this procedure could be used as an important step in syntheses of pyridines and derivatives thereof. They can be used in numerous homogeneous catalytic racemic or enantioselective processes as ancillary ligands and their derivatives (e.g., $\mathrm{N}$-oxides, etc.) as Lewis basic organocatalysts. ${ }^{[1,, c, 9]}$ One such an example is Bolm's ligand, which has the bipyridine scaffold. ${ }^{[10]}$ Therefore, it would be thus desirable to develop the cyclotrimerization of halodiynes with alkynes to substituted halopyridines, because they could serve as convenient intermediates for synthesis of bipyridines and other types of pyridine based ligands.

At the outset, the cyclotrimerization of iododiyne 1a with ethyl cyanoformate 2a as model compounds was screened under different conditions, to explore a possibility for the preparation of iodopyridines (Table 1). The reaction was carried out in dichloroethane (DCE) in the presence of a large excess of cyanoformate (20 equiv.) to ensure high conversion by using the previously reported conditions for Ru-catalyzed cyclotrimerization of iodoalkynes with alkynes 
Table 1. Catalytic cyclotrimerization of 1a with 2a under different conditions.

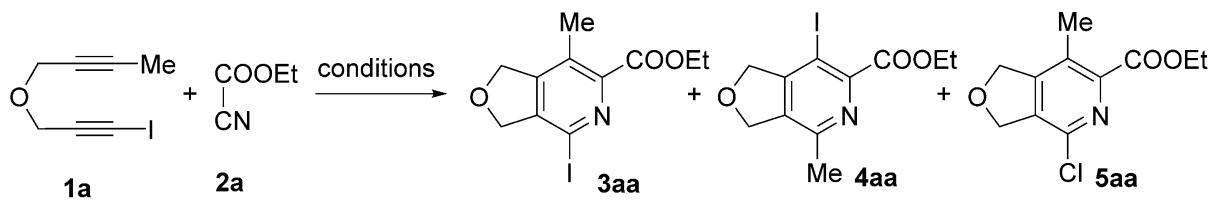

\begin{tabular}{|c|c|c|c|c|c|c|c|c|c|}
\hline \multirow[t]{2}{*}{ Entry } & \multirow[t]{2}{*}{ 2a (equiv.) } & \multirow[t]{2}{*}{ Catalyst $^{[a]}$} & \multirow[t]{2}{*}{$(\mathrm{mol} \%)$} & \multirow[t]{2}{*}{ Time $[\mathrm{h}]$} & \multirow[t]{2}{*}{ Solvent ${ }^{[b]}$} & \multicolumn{4}{|c|}{ Yield $[\%]^{[c]}$} \\
\hline & & & & & & $3 \mathbf{a a}$ & $4 \mathbf{a a}$ & 5 aa & Combined \\
\hline 1 & 20 & $\mathrm{Ru}$ & 6 & 88 & DCE & 23 & 33 & 3 & 59 \\
\hline 2 & 1 & $\mathrm{Ru}$ & 5 & 27 & DCE & $18^{[\mathrm{d}]}$ & $19^{[\mathrm{d}]}$ & $3^{[\mathrm{d}]}$ & $40^{[\mathrm{d}]}$ \\
\hline 3 & 2 & $\mathrm{Ru}$ & 5 & 27 & DCE & $32^{[\mathrm{d}]}$ & $39^{[\mathrm{d}]}$ & $5^{[\mathrm{d}]}$ & $76^{[\mathrm{d}]}$ \\
\hline 4 & 5 & $\mathrm{Ru}$ & 5 & 27 & DCE & $26^{[\mathrm{d}]}$ & $28^{[\mathrm{d}]}$ & $2^{[\mathrm{d}]}$ & $56^{[\mathrm{d}]}$ \\
\hline 5 & 10 & $\mathrm{Ru}$ & 5 & 27 & DCE & $16^{[\mathrm{d}]}$ & $21^{[\mathrm{d}]}$ & $2^{[\mathrm{d}]}$ & $39^{[\mathrm{d}]}$ \\
\hline 6 & 2 & $\mathrm{Ru}$ & 2 & 136 & $\mathrm{DCE}$ & 9 & 7 & 1 & 17 \\
\hline 7 & 2 & $\mathrm{Ru}$ & 5 & 136 & DCE & 19 & 28 & 3 & 50 \\
\hline 8 & 2 & $\mathrm{Ru}$ & 10 & 37 & DCE & 29 & 45 & 5 & 79 \\
\hline 9 & 2 & $\mathrm{Ru}$ & 10 & 39 & DCM & 27 & 38 & 5 & 70 \\
\hline 10 & 2 & $\mathrm{Ru}$ & 10 & 39 & THF & 27 & 45 & 5 & 77 \\
\hline 11 & 2 & $\mathrm{Ru}$ & 10 & 39 & $\mathrm{CHCl}_{3}$ & 35 & 47 & 7 & 89 \\
\hline 12 & 2 & $\mathrm{Ru}$ & 10 & 39 & CPME & 34 & 49 & 5 & 88 \\
\hline 13 & 5 & $\mathrm{Co}^{[\mathrm{e}]}$ & 5 & 82 & toluene & $\mathrm{nr}$ & $\mathrm{nr}$ & - & - \\
\hline 14 & 2 & $\mathrm{Rh}^{[\mathrm{f}]}$ & 2.5 & 36 & DCE & traces & traces & - & - \\
\hline
\end{tabular}

[a] $\mathrm{Ru}=\mathrm{Cp} * \mathrm{RuCl}(\mathrm{cod}) ; \mathrm{Co}=\mathrm{CpCo}\left[\mathrm{P}(\mathrm{OEt})_{3}\right]$ diethylfumarate; $\mathrm{Rh}=[\mathrm{Rh}(\operatorname{cod})] \mathrm{BF}_{4},(R)-\mathrm{BINAP}$. Reactions were run at $20^{\circ} \mathrm{C}$ unless otherwise noted.

[b] $\mathrm{DCE}=1,2$-dichloroethane, $\mathrm{DCM}=$ dichloromethane, $\mathrm{CPME}=$ cyclopentyl methyl ether.

[c] Isolated yields unless otherwise noted; $\mathrm{nr}=$ no reaction.

[d] Yields determined by ${ }^{1} \mathrm{H}$ NMR.

[e] The reaction was run at $100^{\circ} \mathrm{C}$.

[f] The reaction was run at $20^{\circ} \mathrm{C}(20 \mathrm{~h})$ and then at $50^{\circ} \mathrm{C}(16 \mathrm{~h})$.

$\left[\mathrm{Cp} * \mathrm{RuCl}(\mathrm{cod})\right.$ at $\left.20^{\circ} \mathrm{C}\right]$. Gratifyingly, the cyclotrimerization took place and provided three products 3aa, 4aa, and $\mathbf{5 a a}$ in 23,33 , and $3 \%$ isolated yields $(59 \%$ combined yield) (entry 1). Compounds 3aa and 4aa were regioisomers formed by different insertion pathways into the intermediate ruthenacycle, whereas 5aa possessed chlorine instead of iodine. The formation of this compound was a bit puzzling, but subsequent investigation could reveal the origin of its formation (vide infra). Then, the effects of the nitrile/alkyne ratio, catalyst load and solvent on the course of the reaction were explored. The obtained results (entries 2-5) indicated the $2 / 1$ nitrile/diyne ratio to be optimal giving products in $76 \%$ combined yield. Using $10 \mathrm{~mol} \%$ of the catalyst seemed to be optimal for high yields of the products (entries 6-8). As far as the reaction medium is concerned, cyclotrimerization proceeded to give high isolated yields of the products $(77-89 \%)$ in dichloromethane, tetrahydrofuran, chloroform, and cyclopentyl methyl ether (entries 912). Attempts to induce the cyclotrimerization with $\mathrm{Co}$ or $\mathrm{Rh}$ catalysts were not successful, despite the fact that these catalysts were shown to catalyze the cyclotrimerization of iodoalkynes with alkynes. ${ }^{[4,5]}$ In both cases the reaction did not take place; moreover, slight decomposition of iodoalkyne 1a was observed (entries 13 and 14). Although speculative, their inactivity may arise from a competitive oxidative addition of the reactive $s p \mathrm{C}^{-}$-halogen bond that might oxidatively add to these compounds providing catalytically inactive species. ${ }^{[11]}$ With respect to the above described results, the following conclusions could be made on the optimal reaction conditions: (i) $2 / 1$ nitrile/alkyne ratio, (ii) $10 \mathrm{~mol} \%$ of $\mathrm{Cp} * \mathrm{RuCl}(\mathrm{cod})$, (iii) chlorinated solvents as the reaction medium, (iv) reaction temperature of $20^{\circ} \mathrm{C}$. The structure of the regioisomers was unequivocally confirmed by single crystal X-ray analyses of 3aa and 4aa (Figure 1 and Figure 2).

Then the efficacy of the Ru-catalyzed cyclotrimerization of bromo- $\mathbf{1 b}$ and chlorodiynes $\mathbf{1 c}$ with cyanoacetate 2a was examined for comparison under the optimized conditions (Table 2). The reaction with bromodiyne $\mathbf{1 b}$ proceeded with full conversion of the starting material and provided a mixture of $\mathbf{3 b a}, \mathbf{4 b a}$, and 5aa in a combined $91 \%$ isolated yield (entry 2). The use of the chlorodiyne 1c furnished 3ca and 4ca in a lower yield of $72 \%$ (entry 3 ). Obviously, the use of the bromo derivative $\mathbf{1 b}$ was advantageous with respect to yields of products. Attempts to increase the reaction rate of cyclotrimerization of $\mathbf{1 b}$ by using AgOTf to generate a cationic complex ${ }^{[12]}$ or to sup- 


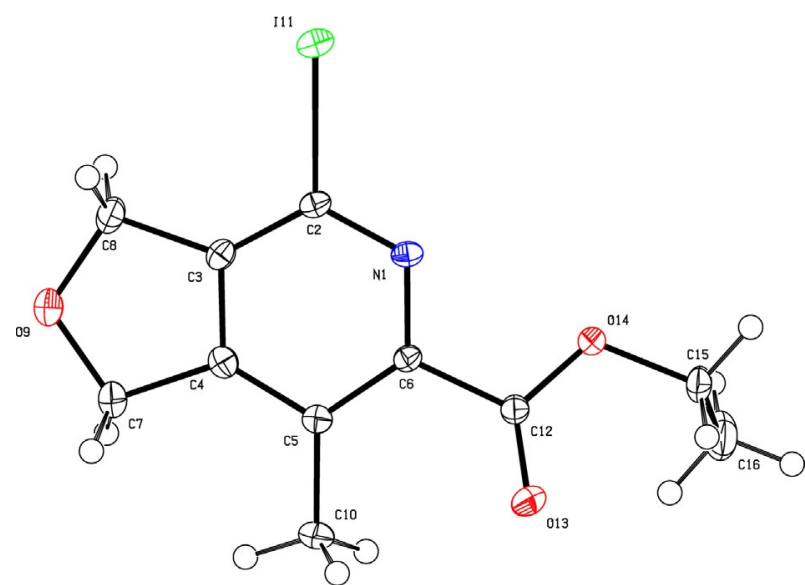

Figure 1. ORTEP drawing of 3aa with $30 \%$ thermal ellipsoids.

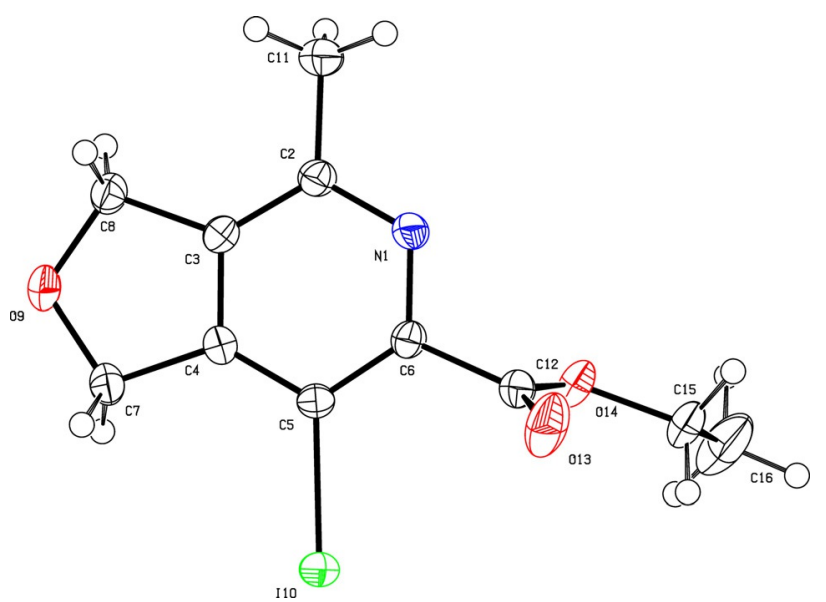

Figure 2. ORTEP drawing of 4aa with $30 \%$ thermal ellipsoids. press formation of $\mathbf{5 a a}$ by addition of $\mathrm{Bu}_{4} \mathrm{NBr}$ did not meet with success. The former resulted in the formation of a complex reaction mixture, in which only traces of the desired products were detected (entry 4). The latter had only a marginal if any effect on the product distribution (entry 5 ).

In order to elucidate the formation of the chloro derivatives, the following experiments were carried out, Firstly, 3aa (containing approximately 12\% of 5aa) was mixed with an equimolar amount of $\mathrm{Cp}^{*} \mathrm{RuCl}(\mathrm{cod})$ in deuterated dichloromethane and stirred at $20^{\circ} \mathrm{C}$. According to the ${ }^{1} \mathrm{H}$ NMR analysis of the reaction mixture (thanks to characteristic signals of 3aa and 5aa) already $50 \%$ of 3aa was converted to 5aa after $10 \mathrm{~h}$ while after 10 days the conversion was $80 \%$ (see Figure SI-1 and Figure SI-2 in the Supporting Information).

A halogen exchange reaction is a synthetically interesting reaction proceeding in the presence of various transition metal compounds, including ruthenium complexes. ${ }^{[13]}$ The Ru-catalyzed halogen exchange has been observed with triflates $\left(\left[\mathrm{Cp} * \mathrm{Ru}(\mathrm{MeCN})_{3}\right] \mathrm{OTf}\right.$ and $\mathrm{LiBr})^{[14]}$ and acyl halides $\left(\mathrm{CpRuCl}\left(\mathrm{PPh}_{3}\right)_{2}\right.$ with $\mathrm{Me}(\mathrm{CO}) \mathrm{X}, \mathrm{X}=\mathrm{Cl}, \mathrm{Br}, \mathrm{I}) .{ }^{[15]}$ As for the reaction mechanism of the Ru-catalyzed halide exchange, two hypotheses have been proposed. The first one assumes the halogen exchange to proceed via oxidative addition forming a cationic Ru(IV) 18 electron complex followed by ligand exchange $\left(\mathrm{TfO}^{-}\right.$for $\left.\mathrm{X}^{-}\right)$and subsequently undergoing reductive elimination. The second one, based on experimental results and DFT calculations, proposes the course of the reaction to proceed via a radical pathway. Since thermochemical data clearly show that in 2-chloropyridine the $\mathrm{C}-\mathrm{Cl}$ bond $\left[\mathrm{BDE}(\mathrm{C}-\mathrm{Cl})=90.5 \mathrm{kcal} \mathrm{mol}^{-1}\right]^{[16]}$ is much stronger than the $\mathrm{C}-\mathrm{I}$ bond in 2-iodopyridine [BDE $(\mathrm{C}-$ $\left.\mathrm{I})=63.1 \mathrm{kcal} \mathrm{mol}^{-1}\right] .^{[17]} \mathrm{We}$ assume this difference in

Table 2. Ru-catalyzed cyclotrimerization of diynes $\mathbf{1}$ with nitrile $\mathbf{2 a}$.

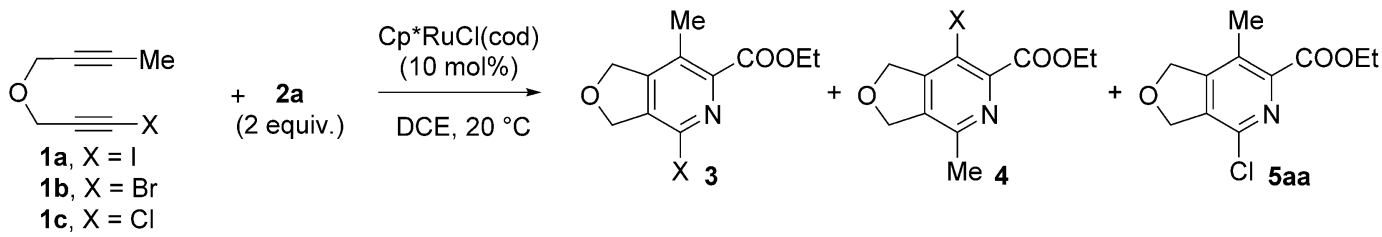

\begin{tabular}{|c|c|c|c|c|c|c|c|c|c|}
\hline \multirow{2}{*}{ Entry } & \multirow{2}{*}{1 (equiv.) } & \multirow{2}{*}{ Time $[\mathrm{h}]$} & \multirow{2}{*}{ Additives } & \multicolumn{6}{|c|}{ Yield [\%] ${ }^{[\mathrm{a}]}$} \\
\hline & & & & & & & & $\mathbf{5 a a}^{[\mathrm{b}]}$ & Combined \\
\hline 1 & $1 \mathbf{a}$ & 37 & - & 3aa & 29 & 4aa & 45 & 5 & 79 \\
\hline 2 & $1 b$ & 21 & - & $3 \mathbf{b a}$ & 40 & $4 \mathrm{ba}$ & 48 & 3 & 91 \\
\hline 3 & 1c & 21 & - & 3ca & 36 & $4 \mathrm{ca}$ & 36 & $-^{[\mathrm{b}]}$ & 72 \\
\hline 4 & $\mathbf{1 b}$ & 39 & AgOTf & $3 \mathbf{b a}$ & traces & $4 \mathrm{ba}$ & traces & traces & - \\
\hline 5 & $\mathbf{1 b}$ & 20 & $\mathrm{Bu}_{4} \mathrm{NBr}$ & $3 \mathbf{b a}$ & 31 & $4 \mathrm{ba}$ & 39 & 2 & 72 \\
\hline
\end{tabular}

[a] Isolated yields.

[b] The compound's structure is the same as that of 3ca. 
bond strength to be the driving force of the reaction. ${ }^{[18]}$ To verify this assumption 2 -iodopyridine was stirred with $\mathrm{Cp} * \mathrm{RuCl}(\mathrm{cod})$ in deuterated dichloromethane. The exchange proceeded in the same fashion, but the reaction rate was much faster: $50 \%$ conversion to 2-chloropyridine was observed already after 5 hours and $90 \%$ conversion after $48 \mathrm{~h}$ (see Figure SI-3 and Figure SI-4 in the Supporting Information). However, attempts to carry out the iodine-chlorine exchange under catalytic conditions $[10 \mathrm{~mol} \%$ $\left.\mathrm{Cp}{ }^{*} \mathrm{RuCl}(\operatorname{cod})\right]$ in the presence of $\mathrm{LiCl}$ (THF, $\mathrm{MeOH}$, $\mathrm{DMF}$ ) or $\mathrm{Me}_{4} \mathrm{NCl}(\mathrm{DCE} / \mathrm{MeOH})$ in various solvents were not met with success and only traces $(\sim 1-2 \%)$ of the desired 2-chloropyridine were observed after prolonged reaction time (1 week) even if the temperature was increased to $50^{\circ} \mathrm{C}$.

Having elucidated the formation of the chloro derivatives, we decided to proceed with an assessment of the reaction scope and the cyclotrimerization of various nitriles $\mathbf{2}$ with $\mathbf{1 b}$ was undertaken (Table 3 ). Although the reaction with cyanoformate $\mathbf{2 a}$ proceeded to give high yields of products (Table 2, entry 2), the reactions with other nitriles gave variable yields. Thus the reaction with cyanoacetate $2 \mathbf{b}$ at 20 or $50^{\circ} \mathrm{C}$ did not yield the desired products. On the other hand, the use of highly electron-deficient malononitrile 2c at $20^{\circ} \mathrm{C}$ provided a mixture of $3 \mathbf{b c}(59 \%)$ and $4 \mathbf{b c}$ $(13 \%)$ yield along with minor amount of 5ac $(2 \%)$ (entry 1). A possible product of the double cyclotrimerization was not observed. A reaction of $\mathbf{1 b}$ with benzonitrile $\mathbf{2 d}$ and 4-chlorobenzonitrile $\mathbf{2 e}$ did not provide the expected products at 20 or $50^{\circ} \mathrm{C}$. Interestingly, reaction with 3,5-difluorobenzonitrile $\mathbf{2 f}$ and 2,4,6-trifluorobenzonitrile $\mathbf{2 g}$ gave opposite results. The former gave rise to $\mathbf{3 b f}$ and $\mathbf{5 a f}$ in $16 \%$ and $3 \%$ isolated yields, respectively (entry 2), whereas $\mathbf{4 b f}$ was formed just in traces $(\sim 1 \%)$. Gratifyingly, the use of highly electron-deficient nitrile $2 \mathrm{~h}$ at 20 or $50^{\circ} \mathrm{C}$ pro-

Table 3. Ru-catalyzed cyclotrimerization of various nitriles $\mathbf{2}$ with $\mathbf{1 b}$.

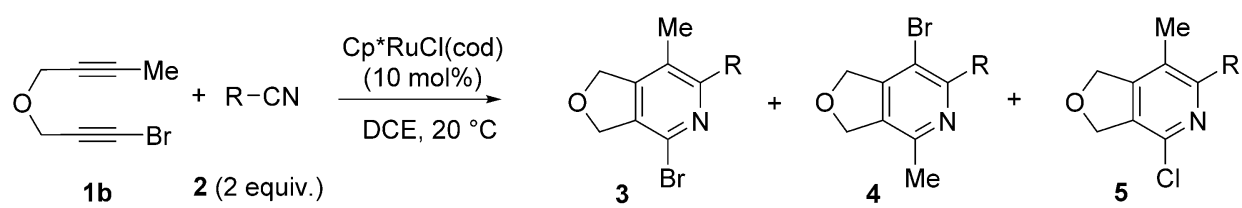

\begin{tabular}{|c|c|c|c|c|c|c|c|c|c|c|c|}
\hline \multirow{3}{*}{$\begin{array}{l}\text { Entry } \\
1\end{array}$} & \multirow{3}{*}{$\begin{array}{l}2 \\
2 c\end{array}$} & \multirow{3}{*}{ 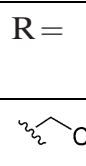 } & \multirow{3}{*}{$\begin{array}{l}\text { Temp. }\left[{ }^{\circ} \mathrm{C}\right] \\
20\end{array}$} & \multirow{3}{*}{$\begin{array}{l}\text { Time }[\mathrm{h}] \\
13\end{array}$} & \multicolumn{7}{|c|}{ Yield [\%] $]^{[\mathrm{a}]}$} \\
\hline & & & & & \multicolumn{2}{|c|}{3} & \multicolumn{2}{|r|}{4} & \multicolumn{2}{|c|}{5} & \multirow{2}{*}{$\frac{\text { Combined }}{74}$} \\
\hline & & & & & $3 b c$ & 59 & $4 \mathrm{bc}$ & 13 & 5 ac & 2 & \\
\hline 2 & $2 f$ & & 20 & 143 & $3 b f$ & 16 & $4 \mathrm{bf}$ & traces & 5af & 3 & 19 \\
\hline 3 & $2 \mathbf{h}$ & & 20 & 40 & $3 b h$ & 30 & $4 \mathrm{bh}$ & $\mathrm{nd}^{[\mathrm{b}]}$ & 5ah & 5 & 35 \\
\hline 4 & $2 \mathbf{i}$ & & 20 & 69 & $3 b i$ & 31 & 4bi & 12 & 5ai & 5 & 48 \\
\hline 5 & $2 j$ & & 50 & 10 & 3bj & 31 & 4bj & 8 & 5aj & 5 & $44^{[c]}$ \\
\hline 6 & 21 & & 20 & 11 & $3 b l$ & 48 & $4 \mathrm{bl}$ & 33 & 5al & 1 & 82 \\
\hline 7 & $2 \mathrm{~m}$ & & 20 & 15 & $3 b m$ & 32 & $4 \mathrm{bm}$ & 11 & 5 am & 2 & 45 \\
\hline 8 & $2 n$ & & 20 & 12 & 3bn & 51 & 4bn & 13 & 5an & 3 & 67 \\
\hline
\end{tabular}

[a] Isolated yields.

[b] nd = not detected.

[c] An inseparable mixture of regioisomers. The ratio was determined from ${ }^{1} \mathrm{H}$ NMR. 
vided $\mathbf{3 b h}$ in $30 \%$ yield, along with a minor amount of 5ah (5\%) (entry 3). Interestingly, formation of regioisomer $4 \mathbf{b h}$ was not detected. The use of electrondeficient nitriles such as 3,5-bis(trifluoromethyl)benzonitrile $\mathbf{2 i}$ and 4-nitrobenzonitrile $\mathbf{2} \mathbf{j}$ resulted in the formation of both regiosiomers. The former furnished 3bi and $\mathbf{4 b i}$ in $31 \%$ and $12 \%$ isolated yields along with 5ai (5\%) (entry 4). The latter furnished 3bj and $\mathbf{4 b j}$ in $27 \%$ and $5 \%$ isolated yields along with 5aj $(6 \%)$. Carrying out the reaction at $50^{\circ} \mathrm{C}$ had only marginal effect on the overall yields of products and provided $\mathbf{3 b j}$, $\mathbf{4 b j}$, and $\mathbf{5 a j}$ in 31,8 , and $5 \%$ yields, respectively (entry 5). Interestingly, the reaction with 1,4-dicyanobenzene $\mathbf{2} \mathbf{k}$ gave rise only to traces of the expected products. Then our attention turned to acyl cyanides such as acetyl cyanide $\mathbf{2 1}$, pivaloyl cyanide $\mathbf{2 m}$ and benzoyl cyanide $\mathbf{2 n}$. In all cases the reaction proceeded at $20^{\circ} \mathrm{C}$ to give mixtures of both regioisomers in good isolated yields (entries 6, 7, and 8). Formation of chloro derivatives 5al-5an was observed in the usual extent (1-3\%). The above mentioned results indicate that only strongly electron-deficient nitriles enter this type of cyclotrimerization reaction. It should be also noted that somewhat better results, that is, up to $15 \%$ higher yields, were obtained with new batches of the catalyst, indicating that the course of the reaction with respect to conversions and yields could be affected by the catalyst quality.

The scope of the reaction with respect to diynes was tested afterwards (Table 4). Cyclotrimerizations were carried out with 1-bromo- 1d, 1-bromo-1'phenyl- 1e, and 1-bromo-1'-trimethylsilyl- 1f dipropargyl ethers giving rise to the corresponding mixtures of regioisomers 3da-3fa and 4da-4fa in good combined yields of 36,55 , and $87 \%$ (entries $1-3$ ). It is worth noting that the reaction with $\mathbf{1 d}$ provided only regioisomer 3da, the other one - 4da - was not detected in the reaction mixture and the reaction had to be carried at $50^{\circ} \mathrm{C}$. Interestingly, a reaction with 1 bromo-1'-cyclopropyl dipropargyl ether $\mathbf{1 g}$ did not proceed at 20 or at $50{ }^{\circ} \mathrm{C}$ (entry 4 ). The discrepancy in reactivity of $\mathbf{1 f}$ and $\mathbf{1 g}$ cannot be simply rationalized in terms of steric hindrance, because according to the Charton parameters, ${ }^{[19]}$ the trimethylsilyl group $(v=$ 1.40) should exert larger steric hindrance than the cyclopropyl group $(v=1.06)$. In addition, a complex reaction mixture was obtained in the reaction with $\mathbf{1 g}$ and, according to its ${ }^{1} \mathrm{H} \mathrm{NMR}$ analysis, the presence of other compounds possessing the cyclopropane ring was not noticed. Hence side-reactions involving cleavage of the cyclopropane ring might hamper the overall outcome of the cyclotrimerization. The use 1bromo-1,6-heptadiyne $\mathbf{1 h}$ did not provide the expected pyridine derivatives 3ha and 4 ha (entry 5); preferential homocyclotrimerization to a bromobenzene SI1 was observed instead. A similar result was observed in cyclotrimerization of diethyl 2-(3-bromoprop-2ynyl)-2-(prop-2-ynyl)malonate $\mathbf{1 i}$ in which homocyclotrimerization to SI-2 was the major reaction pathway. In spite of that, 3ia was isolated in low yield of $12 \%$ and only traces of 4ia were detected (entry 6). On the other hand, cyclotrimerization of diethyl 2-(3-bromoprop-2-ynyl)-2-(but-2-ynyl)malonate $\mathbf{1 j}$ with $\mathbf{2 a}$ proceeded to give $\mathbf{3 j a}$ and $\mathbf{4 j a}$ in 31 and $38 \%$ yields, respectively (entry 7). Cyclotrimerizations of 1-bromo1,7-octadiyne $\mathbf{1 k}$ with $\mathbf{2 a}$ did not give the desired products (entry 8 ). These results are not so much surprising since a similar phenomenon had been ob-

Table 4. Ru-catalyzed cyclotrimerization of various diynes $\mathbf{1}$ with $\mathbf{2 a}$.

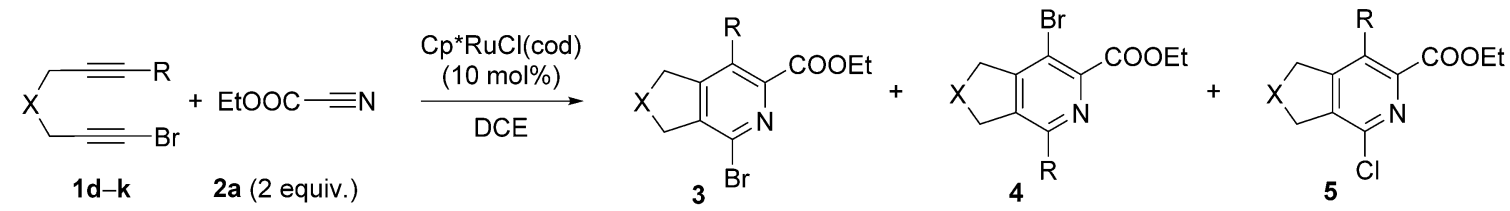

\begin{tabular}{|c|c|c|c|c|c|c|c|c|c|c|c|c|}
\hline \multirow[t]{2}{*}{ Entry } & \multirow[t]{2}{*}{1} & \multirow[t]{2}{*}{$\mathrm{X}$} & \multirow[t]{2}{*}{$\mathrm{R}=$} & \multirow[t]{2}{*}{ Temp. $\left[{ }^{\circ} \mathrm{C}\right]$} & \multirow[t]{2}{*}{ Time $[\mathrm{h}]$} & \multicolumn{7}{|c|}{ Yield [\%] $]^{[\mathrm{a}]}$} \\
\hline & & & & & & & 3 & & 4 & & 5 & Combined \\
\hline 1 & 1d & $\mathrm{O}$ & $\mathrm{H}$ & 50 & 24 & 3da & 32 & 4da & $\mathrm{nd}^{[\mathrm{b}]}$ & $5 \mathrm{da}$ & 4 & 36 \\
\hline 2 & $1 e$ & $\mathrm{O}$ & $\mathrm{Ph}$ & 20 & 22 & 3ea & 32 & 4ea & 17 & 5ea & 6 & 55 \\
\hline 3 & 1f & $\mathrm{O}$ & TMS & 20 & 13 & 3 fa & 44 & $4 \mathrm{fa}$ & 36 & $5 f a$ & 7 & $87^{[\mathrm{c}]}$ \\
\hline 4 & $1 g$ & $\mathrm{O}$ & $c-\operatorname{Pr}$ & 50 & 47 & 3ga & traces & 4ga & traces & $5 g a$ & traces & - \\
\hline 5 & $1 \mathrm{~h}$ & $\mathrm{CH}_{2}$ & $\mathrm{H}$ & 20 & 66 & 3ha & $\mathrm{nr}^{[\mathrm{b}]}$ & 4ha & $\mathrm{nr}^{[\mathrm{b}]}$ & 5 ha & - & $-^{[\mathrm{d}]}$ \\
\hline 6 & $1 \mathbf{1 i}$ & $\mathrm{C}(\mathrm{COOEt})_{2}$ & $\mathrm{H}$ & 20 & 82 & 3ia & 12 & $4 i a$ & traces & $5 i a$ & 2 & $14^{[\mathrm{d}]}$ \\
\hline 7 & $\mathbf{1 j}$ & $\mathrm{C}(\mathrm{COOEt})_{2}$ & $\mathrm{Me}$ & 20 & 18 & 3ja & 31 & $4 \mathbf{j a}$ & 38 & $5 \mathbf{j a}$ & 2 & 71 \\
\hline 8 & $1 k$ & $\left(\mathrm{CH}_{2}\right)_{2}$ & $\mathrm{H}$ & 50 & 24 & $3 \mathbf{k a}$ & traces & $4 \mathbf{k a}$ & traces & $5 k a$ & - & $-[\mathrm{d}]$ \\
\hline
\end{tabular}

[a] Isolated yields.

[b] $\mathrm{nd}=$ not detected, $\mathrm{nr}=$ no reaction.

[c] An inseparable mixture of regioisomers. The ratio was determined from ${ }^{1} \mathrm{H}$ NMR.

[d] Homocyclotrimerization of the starting diyne was observed. 

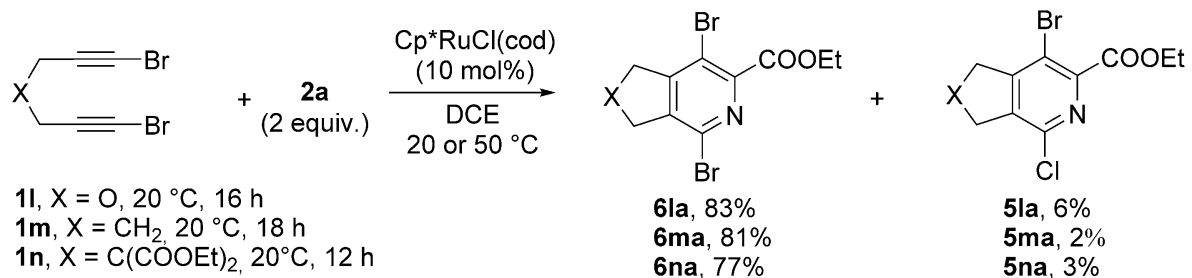

Scheme 1. Cyclotrimerizations of dibromodiynes 11-1n with 2a.

served in $\mathrm{Ru}^{-}{ }^{[4 \mathrm{e}]}$ as well as in Rh-catalyzed ${ }^{[20]}$ cyclotrimerizations of halodiynes previously. It should be noted that in cases of cyclotrimerization of diynes possessing the terminal triple bond $(\mathbf{1 h}, \mathbf{1 i}$, and $\mathbf{1 k}$ ) homocyclotrimerization of diynes was observed as an undesirable side reaction (in case of $\mathbf{1 k}$ only traces of the benzene product were detected by ${ }^{1} \mathrm{H}$ NMR analysis of the reaction mixture).

Finally cyclotrimerization of $\mathbf{2 a}$ with $1,1^{\prime}$-dibromodiynes was screened (Scheme 1). In the case of dibromodiynes 11-1n cyclotrimerization proceeded uneventfully and furnished the desired products 6la-6na in high isolated yields of 83,81 , and $77 \%$, respectively. In all cases also chloro derivatives 5la-5na were formed as minor by-products (2-6\%). As expected on the base of previous results (entry 8, Table 4) cyclotrimerization of 1,8-dibromo-1,7-octadiyne 10 did not give the desired product either at 20 or at $50{ }^{\circ} \mathrm{C}$.

Last but not least, utilization of the prepared bromopyridines $3 \mathbf{b a}$ and $\mathbf{4 b a}$ in cross-coupling reactions
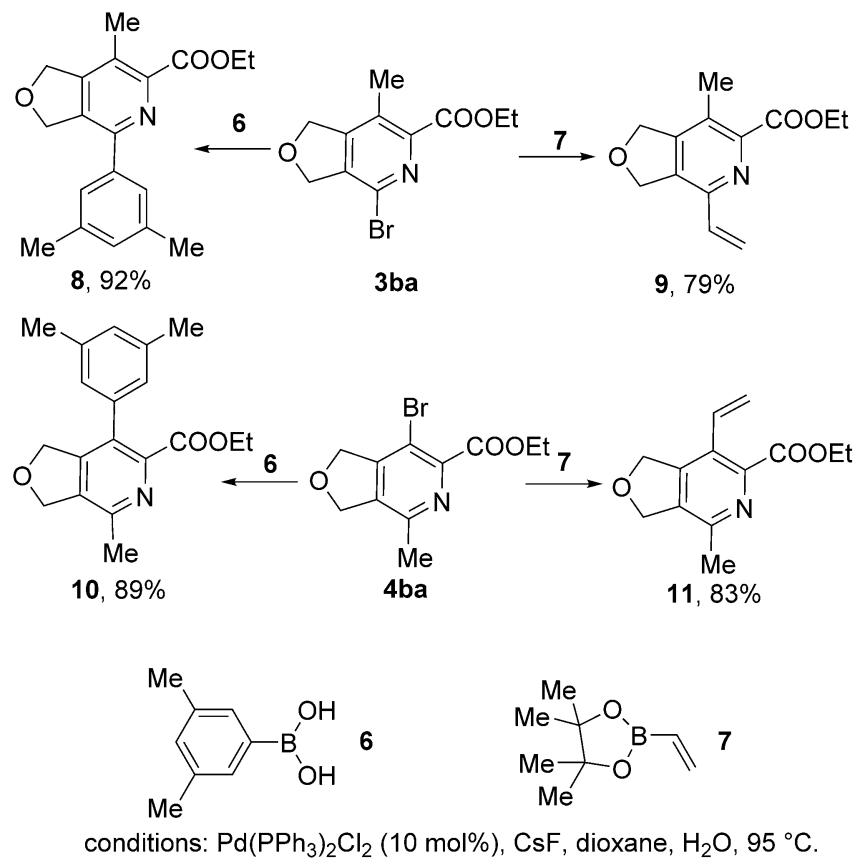

Scheme 2. Cross-coupling of $\mathbf{3 b a}$ and $\mathbf{4 b a}$ with boronic acid derivatives $\mathbf{6}$ and $\mathbf{7}$ under Suzuki conditions. with 3,5-dimethylphenylboronic acid 6 and vinylboronic acid pinacol ester $\mathbf{7}$ was briefly screened (Scheme 2). Thus reaction of $\mathbf{3 b a}$ with $\mathbf{6}$ and $\mathbf{7}$ under the recently reported Suzuki coupling conditions ${ }^{[21]}$ $\left[\mathrm{Pd}\left(\mathrm{PPh}_{3}\right)_{2} \mathrm{Cl}_{2}(10 \mathrm{~mol} \%), \mathrm{CsF}\right.$, dioxane, $\left.\mathrm{H}_{2} \mathrm{O}, 95^{\circ} \mathrm{C}\right]$ provided the expected phenylated and vinylated products $\mathbf{8}$ and $\mathbf{9}$ in very good 92 and 79\% isolated yields, respectively. Analogously proceeded the reactions with 4 ba that gave rise to phenylated and vinylated products $\mathbf{1 0}$ and $\mathbf{1 1}$ in nice 89 and $83 \%$ isolated yields, respectively.

In summary, (i) 1-halo- and 1,7-dibromoheptadiynes could be successfully cyclotrimerized with electrondeficient nitriles to the corresponding halopyridines under catalysis of the Ru-complex $(10 \mathrm{~mol} \%$ of the catalyst is required); (ii) the optimal nitrile/alkyne ratio is $2 / 1$; (iii) the optimal reaction temperature is $20^{\circ} \mathrm{C}$, in the case of less reactive alkynes/nitriles, $50^{\circ} \mathrm{C}$ could be used, (iv) the reaction can be run in different solvents such as chloroalkanes or ethers, (v) for the reactions of $\mathbf{1 a}, \mathbf{1 b}$, and $\mathbf{1 j}$ with $\mathbf{2 a}$ a slight preference for 3-halopyridine is observed, whereas for other cases a slight preference for the formation of 2halopyridines was observed. A brief study regarding cross-coupling reactions of the regioisomeric products was undertaken: both regioisomers reacted almost quantitatively providing basic proof of concept for further functionalization.

\section{Experimental Section}

Ethyl 4-Iodo-7-methyl-1,3-dihydrofuro[3,4-c]pyridine6-carboxylate (3aa), Ethyl 7-Iodo-4-methyl-1,3-dihydrofuro[3,4-c]pyridine-6-carboxylate (4aa), and Ethyl 4-Chloro-7-methyl-1,3-dihydrofuro[3,4-c $]$ pyridine-6carboxylate (5aa)

Into a dried flask containing $\mathrm{Cp} * \mathrm{RuCl}(\mathrm{cod}) \quad(7.6 \mathrm{mg}$, $0.02 \mathrm{mmol})$ under an argon atmosphere, DCE $(1 \mathrm{~mL})$ and nitrile 2a $(40 \mathrm{mg}, 0.4 \mathrm{mmol})$ were slowly added. Then diyne 1a $(47 \mathrm{mg}, 0.2 \mathrm{mmol})$ dissolved in DCE $(1.2 \mathrm{~mL})$ was added during the course of $15 \mathrm{~min}$ and the reaction mixture was stirred at $20^{\circ} \mathrm{C}$. After the full consumption of the starting diyne (disappearance of the respective spot from TLC analysis), volatiles were evaporated under reduced pressure. Column chromatography of the residue on silica gel (gradi- 
ent $10 / 1 \rightarrow 5 / 1$ hexanes/EtOAc) furnished $22 \mathrm{mg}$ of an inseparable mixture of 3aa and 5aa (yields: $29 \%$ and 5\% determined from ${ }^{1} \mathrm{H}$ NMR) and $30 \mathrm{mg}$ (yield: $45 \%$ ) of $\mathbf{4}$ aa as colourless solids. The combined yield is $79 \%$.

3aa: $\mathrm{mp} 168^{\circ} \mathrm{C}$ (for a mixture containing 5aa); ${ }^{1} \mathrm{H}$ NMR $\left(600 \mathrm{MHz} \mathrm{CDCl}_{3}\right): \delta=5.24\left(\mathrm{t}, J=2.4 \mathrm{~Hz}, 2 \mathrm{H}, \mathrm{CH}_{2}\right), 5.05(\mathrm{t}$, $\left.J=2.4 \mathrm{~Hz}, 2 \mathrm{H}, \mathrm{CH}_{2}\right), 4.44\left(\mathrm{q}, J=7.1 \mathrm{~Hz}, 2 \mathrm{H}, \mathrm{CH}_{2}\right), 2.36(\mathrm{~s}$, $\left.3 \mathrm{H}, \quad \mathrm{CH}_{3}\right), \quad 1.42\left(\mathrm{t}, \quad J=7.1 \mathrm{~Hz}, \quad 3 \mathrm{H}, \quad \mathrm{CH}_{3}\right) ;{ }^{13} \mathrm{C} \mathrm{NMR}$ $\left(150 \mathrm{MHz}, \mathrm{CDCl}_{3}\right): \delta=165.23,150.24,148.83,143.74,128.30$, 106.17, 76.44, 74.52, 62.18, 15.76, 14.37; IR (3aa+5aa; drift $\mathrm{KBr}): v_{\max }=2977,1709,1467,1413,1380,1281,1183,1063$, 1099, $905 \mathrm{~cm}^{-1}$; HR-MS (EI-TOF): $m / z=332.9861$, calculated for $\mathrm{C}_{11} \mathrm{H}_{12} \mathrm{NO}_{3} \mathrm{I}(\mathrm{M}): 332.9862 ; R_{\mathrm{f}}(5 / 1$ hexanes/EtOAc $)=$ 0.31 (the same value for 3aa and 5aa).

3ca: $\mathrm{mp} 112.4{ }^{\circ} \mathrm{C} ;{ }^{1} \mathrm{H}$ NMR $\left(600 \mathrm{MHz}, \mathrm{CDCl}_{3}\right): \delta=5.18(\mathrm{~s}$, $\left.4 \mathrm{H}, 2 \times \mathrm{CH}_{2}\right), 4.44\left(\mathrm{q}, J=7.1 \mathrm{~Hz}, 2 \mathrm{H}, \mathrm{CH}_{2}\right), 2.41(\mathrm{~s}, 3 \mathrm{H}$, $\left.\mathrm{CH}_{3}\right), 1.42\left(\mathrm{t}, J=7.1 \mathrm{~Hz}, 3 \mathrm{H}, \mathrm{CH}_{3}\right) ;{ }^{13} \mathrm{C} \mathrm{NMR}(150 \mathrm{MHz}$ $\left.\mathrm{CDCl}_{3}\right): \delta=165.21,153.15,147.58,141.41,136.33,128.08$, 74.08, 73.18, 62.20, 15.88, 14.38; IR (drift KBr): $v_{\max }=1715$, 1470, 1416, 1311, 1290, 1260, 1186, 1066, 1039, $905 \mathrm{~cm}^{-1}$; HR-MS (EI-TOF): $m / z=241.0503$, calculated for $\mathrm{C}_{11} \mathrm{H}_{12} \mathrm{NO}_{3} \mathrm{Cl}(\mathrm{M}): 241.0506$.

4aa: $\mathrm{mp} 113^{\circ} \mathrm{C}$; ${ }^{1} \mathrm{H}$ NMR $\left(600 \mathrm{MHz}, \mathrm{CDCl}_{3}\right): \delta=5.26(\mathrm{t}$, $\left.J=2.1 \mathrm{~Hz}, 2 \mathrm{H}, \mathrm{CH}_{2}\right), 5.06\left(\mathrm{t}, J=2.1 \mathrm{~Hz}, 2 \mathrm{H}, \mathrm{CH}_{2}\right), 4.47(\mathrm{q}$, $\left.J=7.1 \mathrm{~Hz}, 2 \mathrm{H}, \mathrm{CH}_{2}\right), 2.44\left(\mathrm{~s}, 3 \mathrm{H}, \mathrm{CH}_{3}\right), 1.44(\mathrm{t}, J=7.1 \mathrm{~Hz}$ $\left.3 \mathrm{H}, \mathrm{CH}_{3}\right) ;{ }^{13} \mathrm{C} \mathrm{NMR}\left(150 \mathrm{MHz}, \mathrm{CDCl}_{3}\right): \delta=166.17,155.36$, 151.49, 151.02, 135.65, 80.69, 78.74, 73.78, 62.53, 21.70, 14.31; IR (drift $\mathrm{KBr}$ ): $v_{\max }=1730,1419,1377,1335,1308,1204$, 1159, 1060, 905, $854 \mathrm{~cm}^{-1}$; HRMS (EI-TOF): $\mathrm{m} / z=332.9864$, calculated for $\mathrm{C}_{11} \mathrm{H}_{12} \mathrm{NO}_{3} \mathrm{I}(\mathrm{M}): 332.9862 ; R_{\mathrm{f}}(5 / 1$ hexanes/ $\mathrm{EtOAc})=0.16$.

\section{Acknowledgements}

This work was supported by a grant from the Czech Science Foundation (P207/11/0587). The authors would like to thank Dr. Ivana Císařvá (Department of Inorganic Chemistry, Charles University in Prague) for the $X$-ray structure determinations. Financial support from the French Embassy in Prague is acknowledged.

\section{References}

[1] a) G. Zassinovich, G. Mestroni, S. Gladiali, Chem. Rev. 1992, 92, 1051-1070; b) F. Fache, E. Schulz, M. L. Tommasino, M. Lemaire, Chem. Rev. 2000, 100, 2159-2231; c) N. C. Fletcher, J. Chem. Soc. Perkin Trans. 1 2002, 1831-1842; d) E. Meggers, Chem. Eur. J. 2010, 16, 752 758; e) R. H. Doerrer, Dalton Trans. 2010, 39, 3543 3553.

[2] M. D. Hill, Chem. Eur. J. 2010, 16, 12052-12062.

[3] For recent reviews on transition metal-catalyzed $[2+2+2]$ cycloadditions for pyridine synthesis, see: a) N. Weding, M. Hapke, Chem. Soc. Rev. 2011, 40, 45254538; b) Y.-K. Sugiyama, S. Okamoto, Synthesis 2011, 2247-2254; c) M. R. Shaaban, R. El-Sayed, A. H. M. Elwahy, Tetrahedron 2011, 67, 6095-6130; d) G.
Domínguez, J. Pérez-Castells, Chem. Soc. Rev. 2011, 40, 3430-3444; e) D. L. J. Broere, E. Ruijter, Synthesis 2012, 2639-2672. For applications of the metal-catalyzed $[2+2+2]$ cycloaddition reaction in natural product synthesis, see: f) B. Witulski, J. Grand, in: Application to the Synthesis of Natural Products, in: TransitionMetal-Mediated Aromatic Ring Construction, (Ed.: K. Tanaka), John Wiley \& Sons, Hoboken, NJ, USA, 2013, pp 207-254.

[4] Y. Yamamoto, T. Hashimoto, K. Hattori, M. Kikuchi, H. Nishiyama, Org. Lett. 2006, 8, 3565-3568.

[5] a) Y. Yamamoto, K. Hattori, H. Nishiyama, J. Am. Chem. Soc. 2006, 128, 8336-8340; b) Y. Yamamoto, K. Hattori, Tetrahedron 2008, 64, 847-855; c) Y. Yamamoto, R. Takuma, T. Hotta, K. Yamashita, J. Org. Chem. 2009, 74, 4324-4328; d) Y. Yamamoto, K. Yamashita, Y. Harada, Chem. Asian J. 2010, 5, 946-952; e) L. Iannazzo, N. Kotera, M. Malacria, C. Aubert, V. Gandon, J. Organomet. Chem. 2011, 696, 3906-3908.

[6] S. Melnes, A. Bayer, O. R. Gautun, Tetrahedron 2012 , $68,8463-8471$.

[7] K. C. Nicolaou, Y. Tang, J. Wang, Angew. Chem. 2009 , 121, 3501-3505; Angew. Chem. Int. Ed. 2009, 48, 34493453.

[8] J. S. Oakdale, R. K. Sit, V. V. Fokin, Chem. Eur. J. 2014, 20, 11101-11110.

[9] For reviews, see: a) G. Chelucci, R. P. Thummel, Chem. Rev. 2002, 102, 3129-3170; b) S. E. Denmark, G. L. Beutner, Angew. Chem. 2008, 120, 1584-1663; Angew. Chem. Int. Ed. 2008, 47, 1560-1638; c) V. C. Gibson, C. Redshaw, G. A. Solan, Chem. Rev. 2007, 107, 17451776; d) R. P. Wurz, Chem. Rev. 2007, 107, 5570-5595; e) M. Kotora, Pure Appl. Chem. 2010, 82, 1813-1826.

[10] C. Bolm, M. Ewald, M. Felder, G. Schlingloff, Chem. Ber. 1992, 125, 1169-1190.

[11] For oxidative addition of haloalkynes to $\mathrm{Co}, \mathrm{Au}$ and $\mathrm{Pd}$ complexes see: a) D. Cummins, E. D. McKenzie, J. Organomet. Chem. 1975, 87, C19-C21; b) O. Schuster, H. Schmidbaur, Inorg. Chim. Acta 2006, 359, 3769-3775; c) A. Kurbangalieva, D. Carmichael, K. K. (Mimi) Hii, A. Jutand, J. M. Brown, Chem. Eur. J. 2014, 20, 11161125.

[12] A. Goswami, T. Ito, S. Okamoto, Adv. Synth. Catal. 2007, 349, 2368-2374.

[13] For reviews, see: a) A. Vigalok, Chem. Eur. J. 2008, 14, 5102-5108; b) T. D. Sheppard, Org. Biomol. Chem. 2009, 7, 1043-1052; c) A. Vigalok, A. W. Kaspi, Top. Organomet. Chem. 2010, 31, 19-38.

[14] a) E. Shirakawa, Z. Imazaki, T. Hayashi, Chem. Commun. 2009, 5088-5090; b) Y. Imazaki, E. Shirakawa, R. Ueno, T. Hayash, J. Am. Chem. Soc. 2012, 134, 14760-14762.

[15] H. Kuniyasu, A. Sanagawa, T. Nakajima, T. Iwasaki, N. Kambe, K. Bobuatong, M. Ehara, J. Organomet. Chem. 2014, 769, 34-37.

[16] M. D. M. C. Ribeiro da Silva, M. S. Miranda, C. M. V. Vaz, M. A. R. Matos, W. E. Acree, J. Chem. Thermodyn. 2005, 37, 49-53.

[17] E. T. Denisov, Zh. Fiz. Khim. 1995, 69, 623-631.

[18] As for the BDE for $\mathrm{Ru}-\mathrm{Cl}$ and $\mathrm{Ru}-\mathrm{I}$ bonds, only two sets of data are available. The first one shows that $\mathrm{BDE}$ for $\mathrm{Ru}-\mathrm{I}$ is slightly higher than for $\mathrm{Ru}-\mathrm{CI}$, 
whereas the second one provides the opposite result; a) H. E. Bryndza, P. J. Domaille, R. A. Paciello, J. E. Bercaw, Organometallics 1989, 8, 379-385; b) L. Luo, C. Li, M. E. Cucullu, S. P. Nolan, Organometallics 1995, 14, 1333-1338.

[19] M. Charton, Top. Curr. Chem. 1983, 114, 57-91.

[20] a) R. Grigg, R. Scott, P. Stevenson, Tetrahedron Lett. 1982, 23, 2691-2692; b) P. Novák, R. Pohl, M. Hocek, M. Kotora, Org. Lett. 2006, 8, 2051-2054.
[21] S. Wang, X. Li, H. Liu, L. Xu, J. Zhuang, J. Li, H. Li, W. Wang, J. Am. Chem. Soc. 2015, 137, 2303-2310.

[22] CCDC 1442030 (3aa) and CCDC 1442031 (4aa) contain the supplementary crystallographic data for this paper. These data can be obtained free of charge from The Cambridge Crystallographic Data Centre via www.ccdc.cam.ac.uk/data_request/cif. 